\title{
İşletmelerin Satışa Sunacağı Yeni Ürünlerin Pazarda Tutunmasını Etkileyen Faktörler
}

\begin{abstract}
$\ddot{O} z$
Insanlığın varlığı ile ortaya çıkan ihtiyaçlar çeşitli ürün ve hizmetlerle karşılanmaya çalışılmıştır. Ürün ve hizmetler, teknolojik gelişmeler doğrultusunda geçmişten günümüze çeşitlenerek ve yenilenerek gelmiştir. İşletmeler ihtiyaçlara uygun ürünler ve hizmetler sunarken, diğer taraftan teknolojik imkanlarla üretilen yeni ürün ve hizmetler insanların yaşamını kolaylaştırmıştır. Üretim süreci de bu gelişmeler doğrultusunda değişim geçirmiştir. Özellikle Sanayi Devrimi, bu değişimin en önemli tarihsel dönüm noktalarından birisidir. Sanayi Devrimi'nin getirdiği üretimde makineleşme ile başlayan yenilik, bilgi-iletişim teknolojilerindeki hızl gelişmelerle ivme kazanarak devam etmektedir. Bu süreç, bilginin üretilmesini, kullanılmasın ve saklanmasını kolaylaştırmış olup, işletmelerin bir anlamda rekabet avantajlarını eşitlemiştir. Fakat işletmelerin tüketici taleplerini doğru belirleyerek yeni ürünleri üretmesi ve pazarlanmast rekabet üstünlüğü sağlamaktadır.
\end{abstract}

Anahtar Kelimeler: Yeni ürün, pazar, tutunma.

JEL Kodlart: M31, M11, M51.

\section{The Factors Affecting Promotion of New Products Put in Market by the Companies}

\begin{abstract}
The necessities arising from the existence of mankind have been tried to be met with various products and services. Products and services have diversified and renewed from the past in the direction of technological developments. While providing businesses with products and services tailored to their needs, new products and services produced with technological opportunities from the other side have made people's lives easier. The production process has also changed in the direction of these developments. Especially the Industrial Revolution, this change is one of the most important historical turning points. Innovation, which started with the mechanization of production by the Industrial Revolution, continues to gain momentum with rapid developments in information-communication technologies. This process has facilitated the production, use and storage of information, and in a sense the businesses have equalled the competitive advantages. However, enterprises have a competitive advantage in designing and marketing new products by accurately identifying consumer demands.
\end{abstract}

Keywords: New product, marketing, promotion.

JEL Codes: M31, M11, M51.

\footnotetext{
* Prof. Dr., Kilis 7 Aralık Üniversitesi, İktisadi ve İdari Bilimler Fakültesi, İşletme Bölümü, hmpaksoy@yahoo.com, ORCID: http://orcid.org/0000-0001-7975-1795
} 


\section{Giriș}

Küreselleşme sürecinin hız kesmeden devam ettiği bir dünyada işletmelerin ulusal ve uluslararası rekabete dayanabilmelerini etkileyen önemli faktörlerden biride, satışa sunulan yeni ürünlerin pazarda tutunabilmeleridir. Ürünlerin ihtiyaçları karşılaması tüketicilerin satın alma tercihlerini elbette etkilemektedir, ancak bu ürünler yeni teknolojiler kullanılarak tasarım, kalite ve fiyat bakımından daha rekabetçi hale gelebilirler.

Türk Dil Kurumu yenilik kavramını inovasyon bağlamında iki şekilde tanımlamıştır (http://tdk.gov.tr, 30.08.2017): Biri, "varolan bilgi birikiminden yola çıkılarak daha gelişmiş, daha kaliteli, daha işlevsel yeni ürünler, üretim süreçleri, örgütlenmeler ve yönetim uygulamalarının geliştirilmesi” (BSTS / İktisat Terimleri Sözlüğü, 2004), diğeri ise, "değişen koşullara uyarlanmak üzere toplum yaşamında oluşan yeni bir öğe ya da o zamana değin yürürlükte olan uygulayımlardan değişik bir uygulayım” (BSTS / Toplumbilim Terimleri, 1975) şeklindedir. Türkçede 'inovasyon' kavramına tam karşılık gelen bir tabir bulunmamaktadır. Bu nedenle 'innovation' kavramı 'inovasyon' şeklinde Türkçeleştirilmiştir. Bunun haricinde 'yenilik' ve 'yenileşim' şeklinde kullanımlar da mevcuttur. TÜBİTAK, Bilim, Teknoloji ve Sanayi Bakanlığı ve TÜİK gibi resmî kurumlar 'yenilik' kelimesini kullanmaktadırlar (Erdil vd., 2016:12).

İnovativ bağlamında yapılan bu yenilik tanımları, ürünlerin daha işlevsel hale getirilerek değişen koşullara uyarlanmasına vurgu yapmaktadır. Dolayısıyla yeni ürünlerin yenilik kavramının özüne uygun olarak üretilerek pazara sunulması, ürünlerin tutunmasını olumlu yönde etkiyecektir. Bu durum yenilik kavramını, tutunma veya tutundurma açısından ön plana çıkarmaktadır. Pazarlamacılar için yeni ürün ya da yenilik, tüketicilerin yeni ve farklı olarak algıladığı her şeydir. İyi, uzun vadeli yeni bir ürün planlaması, sistematik bir araştırma ve geliştirme gerektirir. Yeni ürün geliştirme ve pazara sunma zor, maliyetli ve tehlikeli bir iş olsa da firmalar için bir mecburiyettir. Yeni ürün geliştirmenin bir diğer nedeni de karlılığ arttırmaktır. Yeni ürün kavramı, orijinal ürün, geliştirilmiş ürün, değiştirilmiş ürün gibi kavramlarla birlikte gündeme gelmiştir. Yeni ürün geliştirme sürecine başlamadan önce ortada bir ürün fikri olmalıdır. Yeni fikirlerin ortaya çıkarılması süreci dikkatli ve sistematik olarak uygulanmalıdır. Yeni ürün fikirlerinden çok azı yapılan tüm analiz ve elemeler sonucunda ürün geliştirme adımına ulaşabilmektedir. Dolayısıyla yeni ürün geliştirme, yüksek maliyetleri yanında etkin pazar araştırmaları ve yoğun ar-ge faaliyetleri gerektiren bir süreçtir.

Pazara sunulan yeni ürünlerin tutunması üzerine yapılan bu çalışma, özellikle literatür taraması yapılarak elde edilen bilgilerin analizi ve sentezini esas almaktadır.

\section{Yenilik ve Yeni Ürünü Geliştirme Süreci}

\subsection{Yenilik ve Yeni Ürün}

Yeni ürün geliştirmek hem pazara yeni giren firmaların pazarda yer edinebilmeleri, hem de pazarda bulunan firmaların varlıklarını sürdürebilmeleri, büyümeleri ve karlarını arttırabilmeleri açısından oldukça önemlidir. Çünkü mevcut ürünler hızla eskimekte, diğer yandan da teknolojik ilerlemeler bu ürünlerin değerini azaltmaktadır. Bu sebeple sadece mevcut ürünler firmaların yaşamlarının devamı için yeterli olmamaktadır.

Yeni ürün geliştirmek veya eski ürünler için yeni kullanım alanları bulmak bir işletmenin devamlılığı ve büyümesinde oldukça önemlidir. Ancak, yeni ürün geliştirmek yetenekli personel, yoğun araştırma, fiziksel kaynaklar ve para gerektirmektedir (Altuğ, 2017:20). 


\subsubsection{Yenilik ve Yeni Ürün Kavramı}

İşletmeler, çoğu kez değişik ürünleri değişik pazarlarda satarlar. İşletme, hedeflediği pazardaki alıcılara hitap eden pazarlama bileşenlerini kullanmak zorundadır. Tüketicinin tavır ve tercihleri ile rekabet şartlarında yaşanan değişimler nedeniyle, pazarlama bileşenlerinde de zamanla değişiklik yapmak zorunda kalabilirler. Bu nedenlerden dolayı işletme pazara yeni ürünler sürüp eskilerinin niteliklerini değiştirmek zorunda kalabilir. Bir ürünün karlı olmasını etkileyecek en önemli neden tüketicinin önem ve tercihleridir (Hatipoğlu, 1993:89). Bu durumda karşımıza yenilik ve yeni ürün kavramları çıkmaktadır.

Yenilikçiliği en çok ifade eden ilk iktisatçı Schumpeter'e göre ekonomik kalkınmaya neden olan yenilikçilik beş şekilde ortaya çıkmaktadır (Alkin, 1992:140'dan akt. Oğuztürk, 2003: 255):

- Yeni tüketim mallarının üretilmesi,

- Yeni üretim yöntemlerinin geliştirilmesi,

- Yeni piyasaların (sektörlerin) oluşturulması,

- Yeni arz kaynaklarının bulunması,

- Yeni endüstriyel örgütlenme şekillerinin ortaya çıkarılması.

Yenilik, pazardaki değişimlere uyum sağlamak amacıyla ürün ve hizmetlerde değişim meydana gelmesidir. Yeni ürün ise firma için herhangi bir yenilik taşıyan üründür (McCarthy ve Perraulant,1990:289). "Yeni ürün" kavramı farklı şekillerde tanımlanmaktadır. Örneğin Gürsel (1979)'e göre, firmanın önceden ürettiği ürünün herhangi bir özelliğinde değişiklik yapılmasını bile yeni ürün geliştirilmesi olarak tanımlamaktadır. Solomon ve Stuart (2002)'a göre yeni ürün kavramı ile ifade edilmek istenen aşağıda verilmektedir:

- Ürün tamamı ile yeni olmalı ya da yeni olarak adlandırılabilecek kadar ciddi bir değişikliğe uğramış olmalıdır.

- Yeni bir ürün sadece 6 ay için yeni olarak nitelendirilebilir.

Pazarlamada yeni ürünler geniş kapsamlı olarak ele alınır ve üç gruba ayrılır ki, bunlar (Altuğ, 2017:21):

- Buluş (icat) anlamında yeni ürün

- Pazar için yeni ürün

- İşletme için yeni ürün

Booz, Allen ve Hamilton tarafından yeni ürünler, firma ve pazara yeniliği açısından da 6 temel bölüme ayrılmıştır (Powers, 1991:199):

- Dünya için yeni: Bu ürünler hem pazar için hem de firma için yeni bir üründür. Bu ürünler yüksek satış potansiyeline sahip olmanın yanı sıra yüksek de risk taşırlar.

- Yeni ürün hattı: Firmanın hâlihazırda bulunduğu pazara yeni bir ürün hattı eklemesidir. $\mathrm{Bu}$ strateji daha az risk taşır çünkü pazar firma tarafından bilinen bir pazardır.

- Mevcut ürün hattına ekleme: Firmanın mevcut ürün hattında genişleme anlamına gelmektedir. Fazla risk taşımamakla birlikte satışları yükseltme konusunda çok fazla potansiyele sahip değildirler. 
- Mevcut ürün hattında revizyon ya da geliştirme: Firma için küçük değişiklikler taşıdığından bir önceki adıma benzer. Bu adım aynı pazar hislerini doldurmak için ürün hattında yapılacak geliştirmelerdir.

- Yeniden konumlandırma: Mevcut ürünlerin yeni pazarlara ya da yeni seğmenlere sunulması anlamına gelir. Bu da yeni ürün hattı gibi yüksek risk taşır.

- Maliyet kesintisi: Maliyet kesintisinde yeni ürün, eski ürünle aynı pazara aynı fonksiyonlarla sunulur. Tek farkı pazara daha düşük maliyetle girilmesidir.

Yeni ürünlerin taşıması gereken kriterleri de şu şekilde sıralayabiliriz (Wilmshurtst, 1988:51):

- Yeni ürün, uygun ve gerçekçi bir talebi karşılamalıdır.

- Yeni ürün, firmanın pazar deneyimi ve kaynakları ile uyumlu olmalıdır.

- Yeni ürün, firmanın mevcut ürünleri ile uyumlu olmalıdır.

- Yeni ürünün pazara sunulması için gerekli finansal altyapı dikkatlice düşünülmeli ve gerekli düzenlemeler yapılmalıdır.

- Yeni ürün geliştirme için uygun yönetim zamanı ayrılmalıdır.

\subsubsection{Yeni Ürünün Önemi}

İşletmeler ürün politikalarını geleceğe dönük planlamalıdırlar. Ne kadar başarılı olursa olsun her ürünün bir ömrü vardır, bu da satışların yüksek seviyelerde kalmasının ve işletmenin karının maksimum düzeyde olmasının sonsuza dek sürmeyeceği anlamına gelmektedir. İşletmeler, sürekli değişiklikler gerçekleştirmeli ve dengeli bir ürün portföyü oluşturmalıdır. Bu nedenle işletmeler için yeni ürün, işletmenin uzun vadeli başarısı için çok önemlidir.

Bazen bir yeniliğin ortaya çıkması yani ürünün piyasaya sürülmesi başka var olan piyasaların yok olmasına ya da oldukça küçülmesine yol açmaktadır. Örneğin elektrik ampulünün icat edilmesi evlerde ve sokak lambalarında gaz kullanımını ortadan kaldırmıştır. Burada unutulmaması gereken önemli nokta, gaz lambaları ortadan kalkmasına rağmen gaz kullanımına dünyada devam edilmiştir. Gaz piyasadan tasfiye olmamıştır. Gaz piyasası da kendini farklı alanlara yöneltmiştir. Yapılan başka yenilikler gazın farklı alanlarda kullanılması sürecini ortaya çıkarmıştır. Örneğin gazla çalışan ısıtma sistemleri ortaya çıkmıştır (Oğuztürk, 2003:258)

Evans ve Berman (1992)'a göre işletmeler için yeni ürünün önemi dokuz başlık altında toplanabilir:

- Yeni ürün, işletmelere farklılık avantajı sağlar. Yeni ürünler işletmenin imajını zenginleştirerek, yenilikçi bir konum oluşturmasını sağlar.

- Bazı işletmeler için yeni ürünler sürekli büyüme için gereklidir. Özellikle rekabetin yüksek olduğu pazarlarda, sürekli bir ürün geliştirmeye ihtiyaç vardır.

- Yeni ürünler daha yüksek kar marjlarına ve işletmenin pazarlama stratejisine hâkim olmasına neden olur. Ürünün pazarda tutunması ve popüler olması ile işletme uygun bir fiyatlandırma politikası sayesinde yüksek kar marjı sağlayabilir.

- Bazı işletmeler riski dağıtmak amacıyla tek ürüne veya ürün dizisine bağımlılığı azaltmak isterler, bu nedenle de yeni ürünlere ihtiyaç duyarlar. 
- İşletmeler, dağıtım kanallarının verimliğini artırmak için yeni ürün sunarlar. Bu sayede reklam ve dağıtım maliyetleri, birden fazla ürüne dağılmış, bayi desteği artırılmış ve potansiyel rakiplerin dağıtım ağına girmeleri engellenmiş olur.

- İşletmeler stratejik açıdan rekabet edebilmek için teknolojiyi kullanmak isterler. Yeni ürün, teknoloji kullanımının yansitılabileceği en güzel yollardan biridir.

- İşletmeler bazen mevcut ürünlerden çıkan artıkları değerlendirerek hem üretkenliklerini artırmayı hem de geri dönüşüme önem vererek çevreye karsı duyarlı olmayı amaçlamaktadırlar. $\mathrm{Bu}$ amaçla yeni ürün geliştirmeye başvururlar.

- İşletmeler müşterilerinin demografik (nüfus, yas, vs.) yapılarındaki ve yasam tarzlarındaki değişikliklere cevap verebilmek için yeni ürün sunarlar.

- Değişmekte olan kanunlara ve yönetmeliklere uymak amacıyla işletmeler, yeni ürün geliştirme yoluna başvururlar.

"İyi, uzun vadeli yeni bir ürün planlaması, sistematik bir araştırma ve geliştirme gerektirir. Yeni ürün fırsatlarının değerlendirilmesi esnasında, işletmenin kaynaklarının, müşteri tarafından işletmenin ürünlerinin algılanma derecesinin, ölçülebilir para ve zaman israfının göz önünde bulundurulması gerekmektedir. Bütün bunlara ek olarak işletmeler yeni ürünün başarısız olabileceği ihtimalini de göz önünde bulundurmalıdırlar" (Evans ve Berman, 1992:279).

Bir firmanın başarısı, firmanın yeni ürün geliștirme yeteneğine bağlıdır. Yeni ürünler ile yeni pazarlar ve büyüme olanakları yaratılabilir. Rekabetçi ortam sürekli bir dinamizm ve gelişim göstermektedir. Bir firma yeni bir ürünü pazara sunması halinde rekabet avantajı elde eder, ancak rakibinin aynı özellikleri taşıyan ona benzer bir ürün sunması her zaman bir tehdit unsurudur. Doğal bir sonuç olarak tüketiciler bu özelliği tüm ürünlerde talep ederler. Bir süre sonra söz konusu özellikler ürün için bir gereklilik halini alır. Bir başka deyişle firmaların rekabet avantajını sağlaması ve koruyabilmesi için yeniliğin devamlılığı esastır (Walley, 1998:186).

Yoğunlaşan rekabet, hızla değişen teknolojiler ve pazar ihtiyaçları ve artan küresel rekabet ürünleri yaşam sürelerini kısaltmıştır (Ringman, 1996:26). Bunun sonucunda hızlandırılmış yeni ürün geliştirme, yeni ürün başarısı ve karlılığı için çözüm olarak görülmektedir (Cooper ve Kleinschmidt, 1994:381). General Elektrik'in başkanı Jack Welch, ortaklara hitaben yazdığı bir yıllık rapor mektubunda, yeni ürünlerini hızlı bir şekilde pazara sunmanın kurumsal öncelik olarak belirlendiğini belirtmiştir (Bayus, 1997:486). Yeni Ürünleri rakiplerden daha hızlı şekilde pazara sunmanın faydaları su şekilde sıralanabilir (Kulwant vd., 1994:5):

- Daha yüksek satış

- Başa baş noktasına daha hızlı ulaşma

- Satışların devamlılığının uzun süre korunmasi

- Pazarda ilk olarak yüksek fiyatlandırma ve dolayısıyla daha yüksek kâr marjları

- Müşteri bağımlılığının sağlanması

- Daha yüksek pazar payı

- Teknolojik üstünlük

- Yenilikçi imajın sağlamlaştırılması

- Ürün yelpazesinin genişlemesi

- Rekabet üstünlüğünün elde edilmesi 


\subsubsection{Yeni Ürün Geliştirme Nedenleri}

Hızla gelişen teknolojik gelişim ve gün geçtikçe artan rekabetçi piyasa ortamı yeni ürün geliştirmeyi zorunlu hale getirmektedir. Yeni ürünler firmaların pazarları ele geçirmesine yol açmaktadır. Bu durum firmalara rekabetçi bir güç vermektedir.

Ürün geliştirmenin başlangıç noktası tüketici ihtiyaçlarıdır (Terpstra ve Sarathy, 1994:311). Mevcut ürünlerle devam edilmesi durumunda satışlar ve karlardaki düşüş devam edecektir. Eğer firma yeni ürün geliştirirse, bu yeni ürün geliştirme kar ve pazar payı artısıyla sonuçlanmaktadır (Shaw ve Bromiley, 1998:41). Pazardaki çeşitli dalgalanmalar talepte daralmalar meydana getirmektedir. $\mathrm{Bu}$ durum firmaların normal üretim faaliyetlerini sürdürmelerini engellemekte, yani âtıl kapasiteyle çalışmalarına neden olmaktadır. İşletmeler daima tam kapasite ile çalışmak arzusundadırlar. Bu sayede malların marjinal maliyetleri düşürülüp yeni yatırımlara kaynak aktarılması ve karın arttırılması sağlanabilir. Bu durumda işletmelerin üreteceği yeni ürünler, âtıl kapasitenin kullanılmasını ve çalışma sürekliliğini sağlayacaktır. Böylece firmalar kaynaklarını daha etkin bir şekilde kullanmış olacaklardır (Gobeli ve Brown, 1987:25).

Yeni ürünler tüketicilere diğer ürünlerden farklı avantajlar sunmaktadırlar. $\mathrm{Bu}$ durum tüketicilerin bu ürünlere yönelmelerine neden olmaktadır. Ayrıca yeni ürünler işletmelerin imajını ve konumunu yenilikçi bir firma olarak arttırmaktadır. Yeni ürünün bir diğer önemli yanı, ürün çeşitliliğiyle işletmenin üstlenmiş olduğu risklerin azaltılmasıdır (Evans ve Berman, 1997). İşletmelerin yeni ürün geliştirmenin öncelikli nedenini, uzun dönemli kar ve büyüme olarak ifade edilebilir (Aydemir, 1998:10). Varlığını sürdürmek isteyen işletmelerin değişime uyum sağlamaları zorunludur. Zira teknolojik gelişmeler, gelişmiş ülkelerde pazarların doyması, artan haberleşme olanakları ve geri kalmış ülkelerde de halkın hızla gelişmiş ülkelerin yaşam düzeyine ve tüketici alışkanlıklarına yönelmeleri yeniliklere olan ilgi ve gereksinimi arttırmaktadır. Ayrıca tüketici gelirlerindeki artış, mevcut ürünler yerine daha iyi, kaliteli olanların talep edilmesi de yeniliği özendiren ve zorlayan etkenler arasındadır (Mucuk, 2000:139). Yeni ürün geliştirme pazarı da genişletir ve böylece sektördeki büyümeyi özendirebilir ve ürün farklılaştırmasını artırabilir. Aynı zamanda ürün yenilikleri yeni gereksinimlere karşılık verilmesini sağlayarak sektörün ikame ürünler karşısındaki konumunu iyileştirebilir ve az bulunur veya yüksek maliyetli tamamlayıcı ürünlere olan gereksinimi azaltabilir (Porter, 2003:210).

\subsubsection{Yeni Ürün Geliştirmede Riskler ve Tehlikeler}

İşletmelerin yeni ürün geliştirmede karşılaştıkları en büyük sorun belirsizlik ve risktir. Teknolojik gelişmelerin çok hızlanması bu belirsizlik ve riskleri daha fazla artırmaktadır. Bir firma tarafından piyasaya sunulan bir ürün çok kısa bir zaman sonra bir başka buluş nedeniyle, yıpranmaya uğrayabilmektedir. Firmalar böyle durumlarda riski ortadan kaldırmak amaciyla çeşitli çabalara girmekte, bu çabalar ise masraf artısına ve zaman kaybına neden olmaktadır. Diğer taraftan günümüzdeki rekabet Sartları da yeni ürün geliştirmenin riskini arttırmaktadır. Ayrıca risk ve belirsizliğe ek olarak yeni ürün geliştirme sürecindeki diğer bir sorun ise bu sürecin pahalı olmasından ortaya çıkmaktadır (Turgay, 1994:66). Ayrıca bu belirsizlik ve risk durumunu artıran diğer bir durum ise, yeni ürün geliştirme zamanının çok uzun olmasıdır. Örneğin, ilk otomatik geçiş milinin araştırılması ve pazara sunulması için 16 yıl, hazır kahve için 22 yıl ve floresan ampul için 33 yıl harcanmıştır (Alpugan vd., 1995). Başarısızlıklar sonucu işletmeler çok büyük finansal maliyetlere katlanmaktadırlar. Ford'un 1958 yılında Edsel modeliyle 250 milyon dolar kaybetmesi, RCA'nın 1981 yılında video-disk oynatıcisıyla 500 
milyon dolar kaybetmesi bu duruma örnek olarak gösterilmektedir (Eugene ve Dwyer, 2000:31).

Yeni ürünün başarısızlığa uğramasının birçok nedeni olabilir. Araştırmalara göre yeni ürünün başarısız olmasının en büyük nedeni, işletmenin, müşterinin istekleri doğrultusunda ürün veya hizmet satamayışıdır. İşletmelerin bunu gerçekleştirememelerinin nedeni ise müşterilerin ihtiyaç ve isteklerinin iyi araştırılmaması veya rakiplerine oranla daha iyi bir performans gösterememiş olunmasıdır (Churchill ve Peter, 1994). Ürünün yanı sıra, pazarlama karmasındaki diğer elemanlar da yeni ürün başarısızlığına yol açabilir. Örneğin pazarlama mesajları hedef pazara ulaşmayabilir veya seçilen dağıtım kanalı uygun olmayabilir. Bunlara ek olarak yeni ürünün başarısız olması şu nedenlere de bağlı olabilir (Kotler, 1998: 307):

- Üst yönetim, olumsuz pazar araştırması sonuçlarına rağmen, yeni ürün fikrinin gerçekleştirilmesini isteyebilir.

- Yeni ürün fikri iyi olmasına rağmen, pazar büyüklüğü olduğundan fazla tahmin edilmiş olabilir.

- Asıl ürün yeteri kadar iyi dizayn edilmemiş olabilir.

- Yeni ürün pazarda yanlış konumlandırılmış, etkin reklamı yapılmamış veya yüksek fiyatlandırılmış olabilir.

- Geliştirme masrafları tahmin edilenden fazla çıkabilir.

- Rakipler sanılandan daha zorlu olabilirler.

\subsection{Yeni Ürün Geliştirme Süreci}

Teknolojik gelişmeler, toplam kalite anlayışı, tüketicilerdeki bilinçlenme vb. nedenler göz önünde bulundurulursa, ürünlerle ilgili yenilik kavramının 1980'li yıllarda başladığı söylenebilir.

Son yıllarda yapılan çalışmalar yeni ürün geliştirmenin başarısını belirleyecek bazı modeller ve varsayımlar ortaya koymuştur. Bunlar, kalite yönetimi, çapraz fonksiyonel takım çalışması, pazar değişim hızı gibi faktörlerin ve çeşitli yönetim araçlarının kullanılmasıyla yeni ürün geliştirmenin başarılı bir şekilde yürütülebileceğini ileri sürmüşlerdir. Diğer taraftan yeni ürün geliştirmede etkili olabilecek yedi kritik faktör olduğu tespit edilmiştir: Bunlar bütün çapraz fonksiyonel takım üyelerince paylaşılan ve rehber niteliğinde olan firmanın yeni ürün geliştirme vizyonu, proje liderliğinin ve organizasyonun yapısı, projeleri sistem yaklaşımı anlayışıyla bir bütün olarak değerlendirme, firmanın öğrenme hızı ve hataları düzeltme gücü, takımların sorumluluk ve sahiplik güdüsünü benimsemesi, şirket performansının ileri atılabilme kapasitesi ve en son olarak da firmanın temel yeteneklerinin kullanma şeklidir (Winer, 2000: 269-285).

Haines (2009) yeni ürün geliştirme aşamalarını planlama ve ürünün devreye girişini esas alarak şu şekilde sıralamıştır:

- Yeni ürün planlamasi

- Kavram

- Uygunluk

- Tanımlama 
- Yeni ürünün devreye girişi

- Geliştirme

- Pazara sunum

Crawford ve Di Benedetto (2008) ise yeni ürün geliştirme sürecini aşağıdaki şekilde sıralamıştır:

- Pazardaki firsatların belirlenmesi

- Kavram geliştirilmesi

- Kavram/Proje değerlendirmesi

- Ürün geliştirme

- Ürünün pazara sunumu

Şekil 1: Yeni Ürün Geliştirme Süreci İçin Bir Örnek

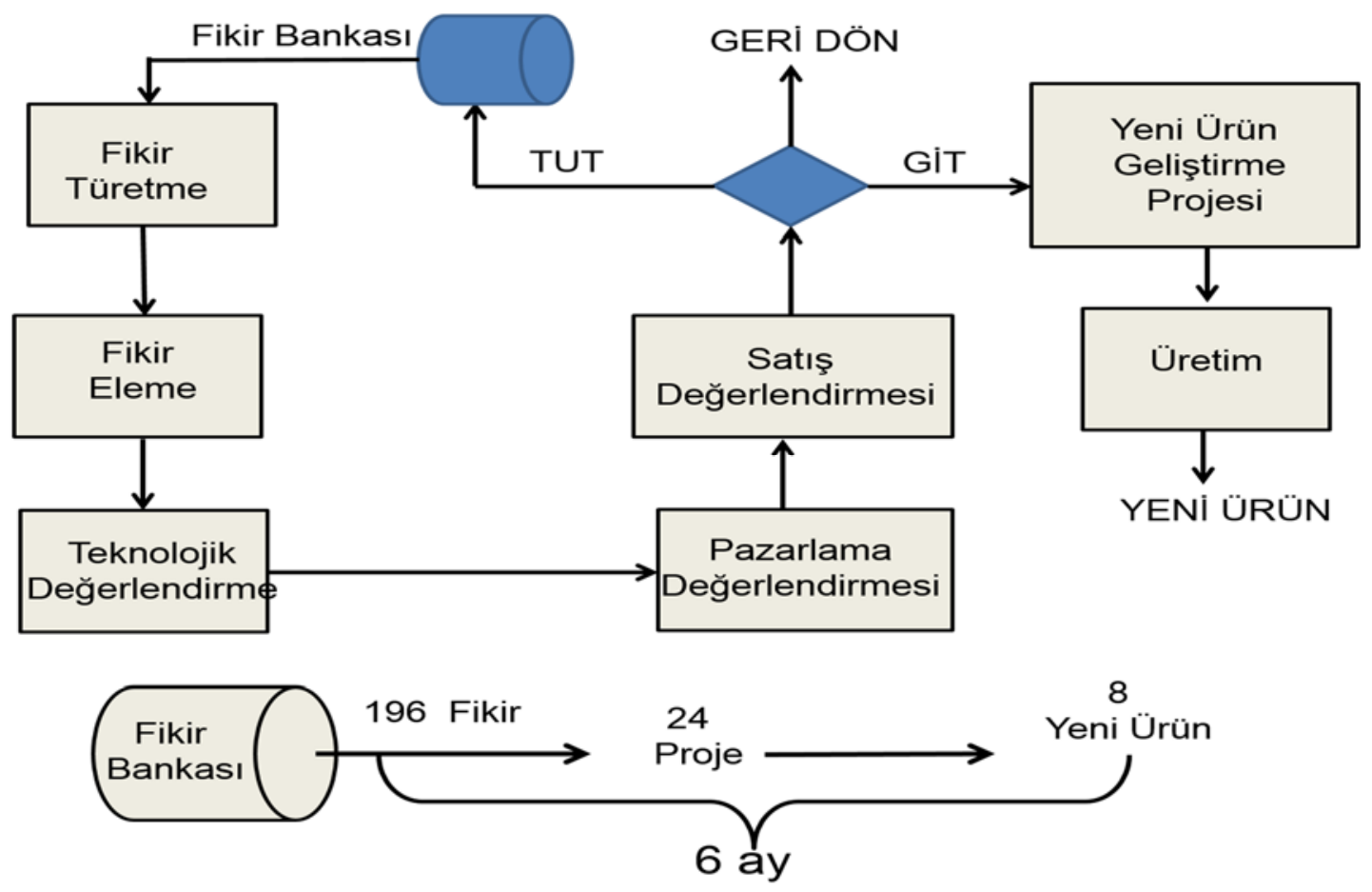

Kaynak: FEŞEL, N. Nilgün (2014), "Yeni Ürün Geliştirme”, Kalkınmada Anahtar Verimlilik Dergisi, Sayı: 30.

Yeni ürün geliştirme sürecinin en temel karar problemlerini (güçlükleri) Kavadias ve Chao (2008) beş boyutta ele almıştır:

- Stratejik bağlantı

- Kisitlı kaynaklar

- Projeler arası etkileşim

- Sonuç belirsizliği

- Problemin dinamik doğas 1 
Evans ve Berman (1992)'a göre yeni ürün geliştirme sürecinde dikkat edilmesi gereken belli baslı konular aşağıda belirtilmiştir:

- Sistematik bir süreç yaratılmalıdır, ancak, her bir yeni ürün firsatının adapte edilebileceği esnek bir süreç olmalıdır.

- Süreç akıcı olmalıdır, yeni ürün sunumunu yavaşlatmamalıdır.

- Doğru buluşlar değerlendirilmelidir, ancak finansal kısıtlamalar asla göz ardı edilmemelidir.

- Müşterinin ürün ile ilgili ön görüsü araştırılıp değerlendirilmelidir, ancak asla potansiyel rakiplere fazla bilgi verilmemelidir.

- Kısa dönem karlılığında bir artış olurken, uzun dönemli büyümedeki masraflarda bir artış olmamalıdır.

Firmalar yeni ürün geliştirme amaçlarını belirledikten sonra bu amaçlara nasıl ulaşacaklarına dair yeni ürün geliştirme stratejileri belirlemelidirler. Ancak bu stratejilerin belirlenmesinden önce firmalar piyasa durumunu ve gelişme eğilimlerini saptamalıdırlar. Yeni ürün geliştirme, ürüne yönelik araştırmaların yapılmasıyla başlar. Yapılan araştırmaların geliştirilmesiyle ve uygulanmaya başlanmasıyla ürüne yaklaşım sağlanmış olur. Uygulanmaya başlanan ürün, nihai geliştirme sürecini bitirdiğinde ürüne ulaşılmış olur. Bütün bu süreç boyunca işletmecindeki takımlar önemli roller oynamaktadırlar.

\section{Yeni Bir Ürünün Pazarda Tutunmasını Etkileyen Faktörler}

Günümüzde firmaların pazara daha sık yeni ürün sunma zorunlulukları birçok ürünün yasam sürecini kısaltmıştır. Bu sebeple bir firmanın mevcut ürün yelpazesi ile uzun süre yüksek kar marjları elde edemeyeceği açıktır. Firmanın toplam karında herhangi bir düşüş yasamaması için firmaların ürün yelpazelerinde yer alan ürünlerin yasam süreçlerinin dengeli bir şekilde dağılımının sağlanması gerekmektedir.

Firmalar; mevcut ürünlerine yeni kullanım alanları yaratarak, ürün üzerinde ufak değişiklikler yaparak, mevcut ürünlerini yeni müşteri gruplarına sunarak veya uluslararası pazarlara açılarak ürünlerinin yasam süreçlerini uzatmayı hedeflerler. Sürecin gelişme aşamasının sonlarına doğru ise firmalar, yeni ürün geliştirerek yeni bir ürün yaşam süreci başlatmalıdırlar. Ürün yaşam süreci üzerinde gerçekleştirecekleri bu uygulamalarla firmalar, kaynaklarını etkin şekilde kullanabilme ve nakit akışlarını artırma şansını elde ederler (Czinkota vd., 1997).

Yeni ürün geliştirmede başlıca başarı faktörleri şöyle sıralanabilir (Winer, 2000:480):

- Müşteri ve tüketicilere yegâne karlar ve üstün değerle farklılaştırılmış ürün, üstün ürün geliştirme.

- Geliştirme sürecinde tamamen pazar oryantasyonuna sahip olunması.

- Tekrar geliştirme ödevinin öne alınması.

- Geliştirmeye başlamadan önce erken ürün tanımlaması.

- Yeni ürün sürecinde aktivitelerin yüksek kalitede olması.

- Uygun organizasyon yapısına sahip olunması.

- Proje seçim kararlarını gerçekleştirmek için olaya öncülük sağlanması. 
- İyi bir plana sahip olunması.

- Tepe yönetim için uygun rolün belirlenmesi.

-Gerçekleştirme kalitesiyle beraber pazara hızlı girilmesi.

-Çoklu aşamaya ve disipline edilmiş yeni ürün oyun planına sahip olunması.

Şekil 2: Yeni Ürün Geliştirmede Başarı Faktörleri

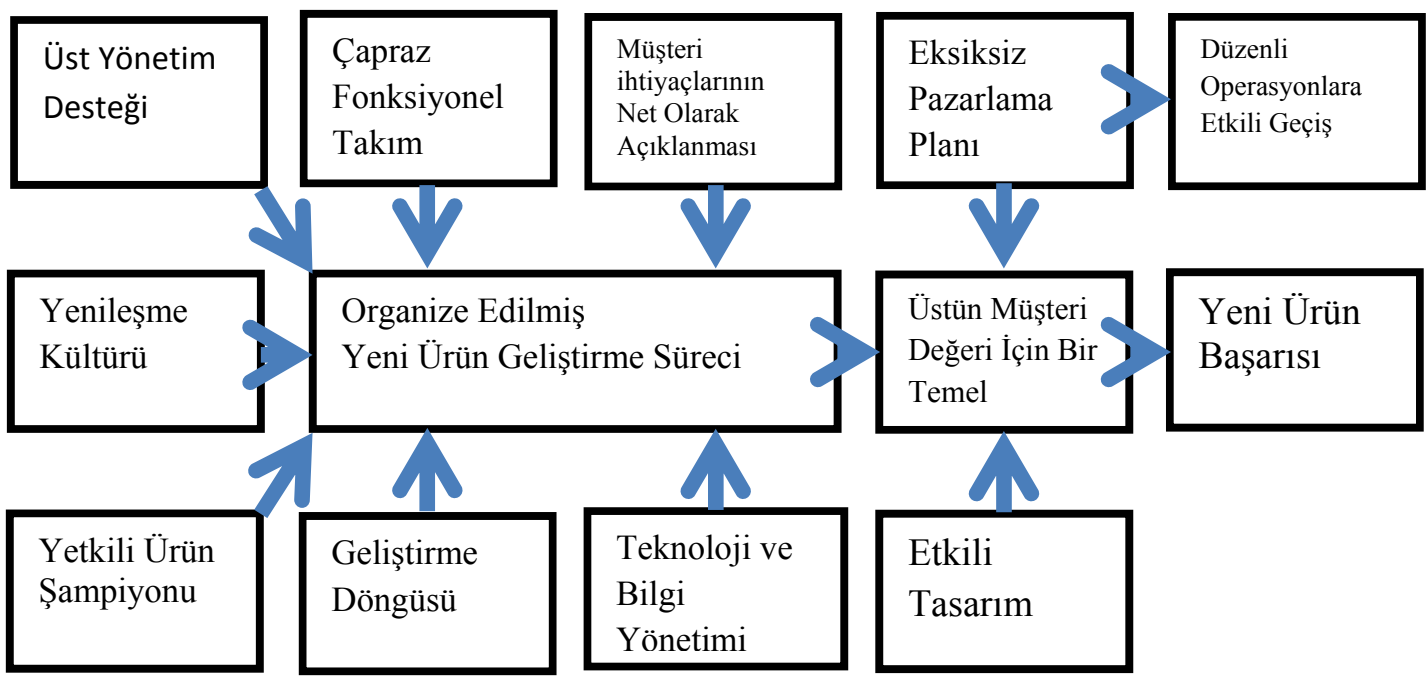

Kaynak: Perreault W., D., Cannon J. P. ve McCarthy, E. J. (2013), Pazarlamanın Temelleri, Nobel Yayınları, McGraw-Hill\&Irwin.

\subsection{Pazar Stratejisi Geliştirme}

Ürün yöneticileri ürünü pazara sunmak için bir ön pazarlama stratejisi belirlemelidir. Pazarlama stratejisi oluşturulurken 3 bölümlü bir çalışma yapılmalıdır. İlk bölüm hedef pazarın büyüklüğü, yapısı, davranışları, ürünün nereye konumlanacağı ve ilk yıllardaki satış, pazar payı ve karlılık hedeflerini tanımlanmasıdır. İkinci aşama ilk yıl için ürünün planlanan fiyatı, dağıtım stratejileri ve pazarlama bütçesi konularını içerir. Üçüncü bölüm ise uzun dönemli satış ve karlılık hedeflerini ve pazarlama karması stratejilerini kapsar (Kotler, 1998:421).

\subsection{Pazarlama İletişimi}

Pazarlama iletişimi, üretilen mal ya da hizmetlerin varlığını tüketiciye duyuran ve işletmenin yaşamasını, gelişmesini sağlayan stratejik bir pazarlama aracıdır (Mucuk, 2000: 168). Pazarlama iletişimi, bir işletmenin ürün ya da hizmetinin satışını kolaylaştıran, müşteriyi ikna ve ürüne ilişkin geri dönüşlerin alınmasına firsat oluşturan çok önemli bir süreçtir. Bu sürecin işletmenin tüm departmanlarıyla koordineli yürütülmesi pazarlama iletişiminin başarısını artıracaktır. Ayrıca pazarlama iletişimi faaliyetlerinin uygulandığı önemli bir alanda internet ve sosyal medyadır. İşletmelerin bu alanları etkin olarak kullanmaları gerekmektedir. Doğru iletişim kurulması ve kullanılması durumunda işletmelerin pazar payını olumlu etkileyecektir. İnternet, yeni bir pazarlama paradigması olarak değerlendirilebilir. 


\section{3. Ürünün Pazara Sunulmasında Reklam ve Marka Bilinci Olușturma Kararları}

Reklam sözcügünün anlamı üzerine çok değişik yorumlar yapılmıştır. Reklam terimi latince kökenli olup çağırmak anlamına gelen "kamere" fiilinden türetilmiştir. Fransızca' da "réclame", Almancada reklam werburg, İngilizce'de "advertisement" olarak karşılık bulmaktadır (Babacan, 2005:7).

TDK (2009) Güncel Türkçe Sözlükte reklam: "Bir şeyi halka tanıtmak, beğendirmek ve böylelikle sürümünü sağlamak için denenen her türlü yol. Bu amaç için kullanılan yazı, resim, film vb." olarak tanımlanmaktadır.

Amerikan Pazarlama Birliği’nin (AMA) tanımına göre reklam; bir ürün, hizmet veya fikrin bedelinin ödenerek, kişisel olmadan açıkça anlaşılabilecek şekilde yapılan, yüz yüze satış dışında kalan tanıtım faaliyetleridir (Türkmen, 1996:23).

Pazarlama iletişimi faaliyetleri içerisinde en fazla payı alan reklam etkinliği için yapılan, genel hatlarıyla benzer olmakla birlikte, değişik nüanslara sahip tanımlamalar bilgi çağının hızlı değişim sürecinde sürekli olarak güncellenme ihtiyacı duymaktadır. Reklam üzerine incelemelerde bulunan Jim Ring, reklamı dört kategoride ele almıştır (1996:86);

- Ürünün farkına varılmasını sağlamak,

- Kişilerin düşüncelerini değiştirmek,

- Kişilerin ürünle ilgili fikirlerini güçlendirmek,

- Eğlendirmek.

Özellikle internetin ve dijital alandaki görsel tasarım araçlarının gelişmesi ve yaygınlaşması ile birlikte reklam türleri ve uygulama şekilleri üzerine çok sayıda değişik fikir ortaya çıkmıştır. $\mathrm{Bu}$ gelişim ve değişim sürecinin pazarlama iletişimi üzerine etkileri konusunda fikir üretenlerden Joe Cappo'nun yakın gelecekle ilgili olarak; televizyon yapımcılarının, interaktif şirketlerin ileri teknolojilerini kullanarak, reklam veren işletmeler ile anlaşmalar yapabileceklerini ve programlarına belirli ürün ve markaları yerleştirebileceklerini öngörmektedir. Ürünlerin bu şekilde konumlandırılmaları, sıradan bir televizyon reklamından daha güçlü etki yaratabilecektir. Bu tür uygulamalar ile reklam kesintisine uğramayan yepyeni bir televizyon programları nesli gelişebilir. Bu reklam filmsiz reklam televizyonu, gerçekçi olmaktan uzak değildir. Gelecek yıllarda reklam sektörünün yoğun olarak tercih edeceği bir başka mecra ise internettir. Reklamcıların ve pazarlamacıların dikkate alması gereken özellikle çocuk ve gençlerin medya tüketim biçimidir. Video oyunları, cep telefonları, bilgisayarlar ile büyümüş olan bu gruplar, teknolojik yönlenmeleri nedeniyle bir medyadan diğerine durmaksızın geçebilme kabiliyetine sahiptirler (Cappo, 2004:171-172, 220).

Marka sözcügü̈, çeşitli uzmanlar tarafından farklı sözcükler ile tanımlanmış ancak ayni temel gerçeklere işaret eden bir kavramdır. Philip Kotlar markayı, ürünün ya da hizmetin üreticisini ya da satıcısını tanıtan bir isim, terim, işaret, sembol, dizayn veya tüm bunların kombinasyonu olarak tanımlamaktadır (Kotler, 2000: 301). Benzer şekilde Amerika Pazarlama Derneği'nin marka tanımı, 'Bir satıcı veya satıcı grubunun ürün veya hizmetlerini tanımlamayı ve rakiplerinden ayrıştırmayı amaçlayan bir isim, bir terim, işaret, sembol veya tasarımdır' seklindedir. David Ogly 'Bir marka, tüketicinin ürüne ilişkin düşüncesidir' demektedir (Elitok, 2003:2). Marka kuramının gurusu David A. Aaker ise markay1 'Ürünleri, ya da bir satıcı veya satıcı gruplarının hizmetlerini tanımlayan ve bu ürün ve hizmetleri rakiplerinden farklılaştıran (logo, trademark, paket dizaynı gibi) ayırt edici isim ve/veya semboldür. Marka bundan ötürü 
müşteriye ürünün kaynağını işaret eder ve hem müşteriyi hem de üreticiyi belirleyici görünen ürünleri temin etmeye çalışan rakiplerinden korur.' seklinde tanımlar (Aaker,1996:56).

Marka adı, markanın daha dar kapsamlısı olup, markanın sözle söylenen kısmıdır. Marka sembolü ise, markanın gözle görülen ancak sözle söylenemeyen kısmıdır. Örneğin Baymak markanın adi, sincap ise sembolüdür. Markalama günümüzde gittikçe daha güçlü hale gelmektedir ki markasız hiçbir ürün ve/veya hizmet kalmamıştır. Tuz, markalanmış ambalajlarda dağıtıcı etiketi ile satılmaktadır. Hatta sebzeler, meyveler ve kümes hayvanları bile markalanmaktadır.

Markalama ise akademisyenler arasında genel kabul gören bir tanım bulamasa da, esasta belirli sektör ve pazarlarda kar getireceği kesin olan servisler ve müşterilerin belirli ürünü seçmesini sağlayan elementler olarak tanımlanabilir. Uzun süredir, markaları fonksiyonel ya da fiziksel niteliklerinin ötesinde başka değerlere sahip oldukları tartışılmaktadır (Lury, 1998: 23). Çağdaş düşünce, klasik marka tanımını pazarlama bölümünün çok ötesine taşımıştır. Nilson markayı stratejik bir iş aracı ve markayı geliştirmeyi de stratejik bir iş aktivitesi olarak tanımlanmaktadır (Nilson,1998: 33).

Kelz ve Bloch da markanın pazarlama faaliyetlerinin ötesinde çalışma olduğunu, organizasyonun bir bütün olarak kucaklanması gereken bir felsefe olduğunu vurgulamışlardır (Kelz, 1998: 56). Ayrıca marka bilgisi, şirketlerin tüketiciler ile daha iyi iletişim sağlama olanaklarını kısıtlayan soyut bir platformun çok ötesinde yer alan pazarlama aracıdır. Markanın duygusal boyutu, zorlayıcı ve yenilikçi marka kimliklerinin tüketici isteklerini yönlendirmesi ve süreci kazanması açısından oldukça önemlidir. Önemsiz fonksiyonel nitelikler ve kalitenin tutarlılığı, marka kimliğinin farklılaştırılması açısından artık yeterli değildir (Nilson, 1998: 35).

Bu noktada marka stratejilerinin önemini belirlemede, ürün ve marka arasındaki farkın da ortaya konulması gerekmektedir. Bir ürün, pazara tüketilmek üzere sunulmuş tüketici istek ve ihtiyaçlarını karşılayan herhangi bir şey olabilirken, marka bu tanıma farklı bir boyut ekleyen ve ayni istek ve ihtiyaçları karşılamak üzere diğer ürünlerden ayrılan özel bir ürün durumuna geçmektedir. Bu ayrımı sağlayan farklar sembolik, duygusal, rasyonel ya da gerçek olabilir (Keller, 2001:17).

Markanın kendine özgü olup olmadığına da karar veren firma değil, tüketicidir. O halde bir firmanın tüketici gözünde gerçek markalar yaratabilmesi için bazı beklentileri karşılaması gerekmektedir. Bunlar (Knapp, 2000:1):

- Gerçekten kendine özgü mü yoksa sadece tarz olarak farklı mı?

- Tüketiciye belirli duygusal ve işlevsel getiriler sağlamayandanmış mı?

- Vaatlerini daima yerine getirir mi, hizmeti, söz verdiği gibi ulaştırır mı?

Bu sorulara 'evet' cevabini verebilen markalar gerçek markalardır. Bir marka, tüketici zihninde ne kadar ayrıcalıklı hale gelirse, o ölçüde 'gerçek marka' olur. Gerçek markaların amacı, insanların yaşamına değer katmak olmalıdır.

\subsection{Belirsizlikten Kaçınma}

Bir toplumun üyelerinin risk alma ya da riskten kaçma hareketlerine yön veren belirsizliğe kars1 tutumlarını ifade eder. Belirsizlikten kaçınmanın düşük olduğu ve risk alma eğiliminin yüksek olduğu toplumlarda yaşamın getirdiği belirsizlikler normal olarak kabul edilir. Ekonomik riskler çoğu zaman ödül anlamına gelir. Kural ve prosedürlerden çok, esneklik ve uyum 
önemlidir. Belirsizlikten kaçınmanın yüksek olduğu ve risk almayı sevmeyen toplumlarda ise belirsizlik endişe kaynağıdır. Ekonomik riskler tedirginlik ve psikolojik stres anlamına gelir. Güven endişesi doğar. Yazılı kural ve prosedürler ön plandadır. Toplum düzenine aykırı davranışlar hoş görülmezler. Belirsizlikten kaçınmanın yüksek olduğu toplumlarda bireyler ancak risk ve sorumluluk birden fazla kişiye ya da topluluğa yayıldığı zaman söz konusu baskıyı üzerlerinde hissetmezler (Süzen, 2001:13).

Belirsizlikten kaçınmanın yüksek olduğu toplumlar, risk ve değişimden kaçınarak, istikrar ve tahmin edilebilirlik ararlar. $\mathrm{Bu}$ tip toplumlar bilinmeyen gelecekle ilgili tereddütlerini, kanunlar ve sosyal normlar gibi çeşitli kontrol mekanizmaları aracılığıyla kısıtlamaya çalışırlar (Nakata ve Sivakumar, 2001:8).

Bireylerin belirsizliği kabullenebilmeleri, önemli ölçüde toplumsallaşma süreçleri sonucunda şekillenir. Belirsizlikten kaçınma eğiliminin baskın olduğu toplumlarda bireyler, yaşantılarını belirleyen kural ve yasalara ihtiyaç duyar, yenilikten kaçınırlar. Bu kültürlerin örgütlerinde de yüksek biçimsellik ve uzmanlaşmanın egemen olduğu bir yapılaşma ortaya çıkacaktır. Aynı şekilde, sorumluluk, yetki alanları ve is tanımları ayrıntılı bir şekilde tanımlanacaktır.

Belirsizlikten kaçınma dereceleri düşük olan toplumların temel özelliklerimle yüksek olan toplumların temel özellikleri Tablo 1'de karşılaştırılmıştır.

Tablo 1: Belirsizlikten Kaçınma Derecelerinin Karşılaştırılması

\begin{tabular}{|l|l|}
\hline Düşük belirsizlikten kaçınma & Yüksek belirsizlikten kaçınma \\
\hline Belirsizlik yaşamın normal bir özelliğidir. & $\begin{array}{l}\text { Yaşamın doğasında olan belirsizlik mücadele } \\
\text { edilmesi gereken bir tehdittir. }\end{array}$ \\
\hline Toplumda düşük kaygı düzeyi. & Toplumda yüksek kaygı düzeyi. \\
\hline Farklı olan heyecanlıdır. & Farklı olan tehlikelidir. \\
\hline Yasamı günü gününe kabul etme. & Geleceğe ilişkin büyük kaygılar taşımak. \\
\hline Bilinmeyen tehlikelere karsı rahatlık. & Bilinmeyen tehlikelere karsı endişe. \\
\hline Zaman yönlendirme aracıdır. & Zaman paradır. \\
\hline Sadece ihtiyaç olduğunda çalış̧a. & Çalışmaya karsı özel istek. \\
\hline Yeni fikir ve davranışlara tolerans. & Yeni fikir ve davranışlara direnç. \\
\hline Genel ve az sayıda kurallar. & Kesin ve çok sayıda kurallar. \\
\hline Protesto kabul edilebilir bir davranıştır. & Protestoların bastırılması gerekir. \\
\hline Tolerans, 1lımlılık. & Tutuculuk, aşırıllık, kanun ve düzen. \\
\hline Gençlere karsı pozitif tutumlar. & Gençlere karsı negatif tutumlar. \\
\hline $\begin{array}{l}\text { Bir gurubun doğruları başkalarına zorla kabul } \\
\text { ettirilemez. }\end{array}$ & Sadece bir tek doğru vardır. \\
\hline Psikoloji ve bilimde deneycilik eğilimi. & Psikoloji ve bilimde büyük teorilere eğilim. \\
\hline
\end{tabular}

Kaynak: Hofstede, Geert (1983), Cultures And Organizations, s. 37, 43.

\subsection{E-Ticaret}

Günümüzde teknolojinin ivme kazanmasıyla beraber bilgi teknolojileri de paralellik göstermiş ve hızlı bir gelişim kaydetmiştir. İnternetin gündelik hayatımıza adım atmasından sonra kendi başına yeni bir sektör haline gelen E-ticarette bu gelişmelerden nasibini almıştır. Hatta bazı Ülkelerin geçim sektörü haline bile gelmiştir. Dünyadaki kriz ve dalgalanmalara rağmen ekonominin kötü gidişatlarına bağlı kalmaksızın e-ticaret sektörü çığ gibi büyümeye ve kıtaları fethetmeye devam etmiştir. E-ticaretin tarihçesi de 1990' l1 yıllara uzanmaktadır. E-ticaretin 
tarihçesi kimimizin çocukluk yılları kimimizin de gençlik yıllarına denk gelmektedir. Eticaretin gelişim ve büyümesinde etkili birçok faktör yer almaktadır. Bunların en etkilisi olarak nüfusun hacmi gösterilirken, İnternetin yaygınlığı, ödeme alternatifleri, taşıma işlemlerinde ki gelişme gibi konularda önemli faktörler arasında kendine yer edinmektedir. Türkiye bu noktada avantajlı bir konumda yer alıyor da diyebiliriz. İnternet kullanımı giderek artmış ve 50 milyona ulaşmıştır. Ülkemiz şu anda Avrupa'da internet kullanımında 6. sırada yer almaktadır. Bunun yanı sıra genç ve dinamik nüfusa ev sahipliği yapan Türkiye yüksek teknolojilere adapte süresince en kısada aktif olmakta ve bu da diğer teknolojik gelişmelerin başını çekmektedir (http://www.rgsyazilim.com/e-ticaretin-tarihcesi/, 20,06.2017).

Son dönemlerde bilgi ve iletişim teknolojilerinde meydana gelen hızlı gelişmeler, insanların hayatını kolaylaştırmaktadır. Bu hızlı gelişmelerden birisi de E-ticarettir. E-ticaret küreselleşme açısından çok önemli bir adımdır. Mal ve hizmetin satın alınması ve satılması ticareti kapsamaktadır. Bu sürecin elektronik ortamda, internet üzerinde yapılması E-ticaret kavramını ortaya çıkarmıştır.

WTO (Dünya Ticaret Organizasyonu), mal ve hizmetlerin üretim reklam satış ve dağıtımlarının telekomünikasyon ağları üzerinden yapılmasıdır. CEFACT (Birleşmiş Milletler Yönetim Ticaret ve Ulaştırma İşlemlerini Kolaylaştırma Merkezi): “İş, yönetim ve tüketim faaliyetlerinin yürütülmesi için yapılanmış ve yapılanmamış iş bilgilerinin, üreticiler, tüketiciler ve kamu kurumları ile diğer organizasyonlar arasında elektronik araçlar (Elektronik posta ve mesajlar, elektronik bülten panoları, WWW teknolojisi, akıllı kartlar, elektronik fon transferi, elektronik veri değişimi vb.) üzerinden yapılmasıdır OECD (İktisadi İşbirliği ve Kalkınma Teşkilatı): Sayısallaştırılmış yazılı metin, ses ve görüntünün işlenmesi ve iletilmesine dayanan, kişileri ve kurumları ilgilendiren tüm ticari işlemlerdir (Ene, 2002:2-3).

E-Ticaret yalnızca ödeme yöntemlerinin ve satışın yeniden tanımlanması değil, "paranın yeniden şekillendirilmesidir. İnternetin 1990'l y ylların ortalarında bir iş yapma yöntemi olarak kullanılmaya başlanması ile geleceğin belirsizleştiği bir ortamda güçlü bir potansiyel ortaya çıkmıştır. Burada ticaret ya da satış kelimeleri, müşteri ile işletme arasında gerçekleşen çalışmaları kapsadığı gibi, işletmeler arası ticareti de kapsamaktadır. Bilgi değişiminde kullanılan araçların temelinde yer alan internet ile birlikte e-mail, intranet, extranet, EDI ya da yalnızca World Wide Web kullanılarak iletişim gerçekleştirilebilir (Dolanbay, 2000: 33). Eticaret, "mal ve hizmetlerin internet üzerinden alım-satımı" olarak tanımlanmaktadır. E-ticaret olarak değerlendirilen işlemler arasında perakende ticaretin yanı sıra, seyahat harcamaları, dijital uygulama indirme, tüketiciler ya da işletmeler arası platformlarda gerçekleşen alışverişler de bulunmaktadır. E-ticaret faaliyetleri, alışverişi gerçekleştiren oyuncuların niteliğine göre 2 gruba ayrılmaktadır (Sezgin, 2013:1).

- Business to Business (B2B): İşletmeler arası ticaret

- Business to Consumer (B2C): İşletme ile tüketici arasındaki ticaret

Ayrica, B2C kategorisinin altında, tüketiciler aras1 (consumer to consumer- C2C) ve arkadaşlar arası (peer to peer-P2P) online ticaret işlemleri de bulunmaktadır. Bu kapsamda, $\mathrm{C} 2 \mathrm{C}$ ticareti gerçekleştiren aracı platformlar birer e-ticaret firması olarak faaliyet göstermektedir (Sezgin, 2013:1).

İstatistiklere göre dünya nüfusunun yaklaşık \%46'sı, diğer bir ifadeyle 3,4 milyar insan internet kullanıcısı haline gelmiştir. 2000 yılından bu yana dünya nüfusu yılda ortalama $\% 1,1$ artış gösterirken, internet nüfusu denilen toplam internet kullanıcı sayısı her yıl yaklaşık $\% 13,2$ artış göstermiştir. 80 milyona yaklaşan nüfusu ile dünyanın en kalabalık 19. ülkesi olan 
Ülkemiz toplam 46,2 milyonluk internet kullanıcısı ile dünyanın en çok internet kullanıcısı olan 17. ülkesi olmuştur. $\mathrm{Bu}$ artış, e-ticarette de artış getirmiş̧ir. Küresel perakende e-ticaret hacmi 2016 itibarıyla 1,6 trilyon ABD doları seviyesine ulaşmıştır. 2011 yılında gelişmekte olan ülkeler hacmin $\% 32$ 'sini oluştururken, bugün bu oran $\% 59$ seviyesine ulaşmıştır. 2020 yllında ise toplam hacmin \%64'ünü gelişmekte olan ülkeler tarafindan oluşturulması beklenmektedir. $\mathrm{Bu}$ değişimde, artık dünyanın en büyük e-ticaret pazarına sahip olan Çin'in etkisi büyüktür. 2011 yllında dünyada toplam perakende içerisindeki payı \%3,6 olan e-ticaretin 2016'daki payı ' 8,5 'e yükselmiştir. 2021 yılında bu oranın $\% 13$ seviyesine ulaşması beklenmektedir. Türkiye'de 2012 y1lında \%1,7 olan e-ticaretin toplam perakende içerisindeki pay1 2016 itibarıla \%3,5 seviyesine yükselmiştir. Çin'in \%17,1, İngiltere'nin \%14.9, ABD'nin \%10.5 seviyelerine ulaştığı perakende e-ticaret sektöründe Türkiye için kat edilebilecek uzun bir yol bulunmaktadır (https://www.slideshare.net/webrazzi/trkiye-eticaret-raporu-2017-turkish-ecom merce-report, 17.09.2017).

\subsection{Yeni Ekonomide Rekabet}

Dünyada, 20. yüzyılın sonunda ABD'de başlayıp, diğer gelişmekte olan ülkelerin ekonomik yapılarını da etkileyen ve bugün de etkisini kaybetmeden devam ettiren bir değişim yaşanmaktadır. Sanayi Devrimi'nde olduğu gibi, bu değişim dalgası toplumları, ülkeleri, kurumları ve sistemleri etkilemektedir. Sanayi Devrimi'nin öncü şehri İngiltere'nin Manchester şehri iken, bugünkü değişimin öncüsü ABD'nin Silikon Vadisi'dir. Bilgi ve iletişim teknolojilerinde yaşanan çok hızlı değişim, artık tüm dünyayı sarmış durumdadır. Yeni teknolojiler, yeni bir kültürü, yeni bir toplumsal yapıyı ve yeni bir ekonomik sistemi de beraberinde getirmiştir (De Long, 1998:14-15'den akt. Bayraktar ve Kaya, 2016:90).

"Yeni ekonomi"den, "gelecek ekonomi"den ya da "bilgi ekonomisi"nden ne anlaşılacağını ifade etmek oldukça zordur. Bu yeterince açık değildir. Ancak her ne olursa olsun yüksek teknolojiyi içerdiği ve yüksek teknolojinin çok önemli bir paya sahip olduğu açıktır (Malpezzi, 2002:323). Yeni ekonomi olarak adlandırılan yeni sistemde tüketim alışkanlıklarından rekabet anlayışına varıncaya kadar her alanda birtakım değişikliklerin yaşandığı görülmektedir. Yeni ekonomik sistemde dünya ekonomisi, sanayi ağırlıklı ekonomik yapıdan, bilgi ve hizmet ağırlıklı bir ekonomik yapıya dönüşmektedir. Günümüze kadar geliştirilen iktisadi sistemlerin kavramakta zorlandığı ekonomik yapı kendine özgü birtakım özellikler barındırmaktadır. Bu nedenle bu sisteme "Yeni Ekonomi" adı verilmiş̧tir (Yumuşak vd., 2009: 22'dan aktaran Bayraktar ve Kaya, 2016: 90). Yeni ekonomi, küreselleşme ve bilgisayarlaşma yolu ile modern ekonomik sistemi kuşatmaktadır. Bilgi ve iletişim teknolojilerinde yaşanan önemli gelişmeler neticesinde ortaya çıkan sistemin modern ekonominin anlaşılabilmesi açısından önem taşıdığı görülmektedir (Stiroh, 1999: 82'dan aktaran Bayraktar ve Kaya, 2016: 90). Yeni ekonomin bazı temel özellikleri bulunmaktadır. Bu özelliklerin belirtilmesi ekonomik yapının anlaşılmasını sağlayacaktır. Yeni ekonomide firmalar yüksek sabit maliyetlere ve düşük marjinal maliyetlere sahiptirler. Bunun nedeni, ürün geliştirme aşamasında (Ar-Ge) yüksek maliyetlerin olmasıdır. Ürün geliştirilip, üretime geçildiği zaman ise firmalar yeni ürün başına maliyetlerini çok düşük seviyelere indirebilmektedir. Yeni ekonomi bir ağ ekonomisidir. Bilgisayar yazılımlarının, internetin ve telekomünikasyon sisteminin hayatımızın her alanına girmesi neticesinde oluşan bu durum kişileri, kurumları ve firmaları da etkisi altına almıştır. Yeni ekonomik sistemde rekabet, sistemin temel direğidir. "Kazanan her şeyi alır anlayışı" yeni ekonomik sistemin karakteristik özelliklerinden birisidir (Evans and Schmalensee, 2001: 7-11'den akt. Bayraktar ve Kaya, 2016:90). 
Porter'a göre bir endüstrinin veya sektörün rekabet yoğunluğunu ve böylelikle de çekiciliğini etkileyen beş önemli unsur vardır (http://stratejinibelirle.blogspot.com.tr/2012/05/ rekabetin-5-onemli-unsuru.html, 18.09.2017). Bunlar:

- Yeni rakiplerin tehdidi,

- İkame ürünlerin tehdidi,

- Müşterilerin pazarlık gücü,

- Tedarikçilerin pazarlık gücü ve

- Sektör içi mevcut rekabetin yoğunluğu olarak sıralanmaktadır.

\section{Sonuç}

Küresel ve teknolojik gelişmeler, bir yandan pazarlama kavramının yeniden şekillenmesine, diğer yandan etkileşime ve kullanıcı katılımına olanak tanıyan sonuçlar doğurmuştur. Günümüzde çoğu işletme, bütünsel pazarlama anlayışını benimseyerek, hedef pazardaki bireysel müşterileri yakından takip etmeyi ve onlarla yaşam boyu sürecek ilişkiler kurmayı hedeflemektedir. Bu çerçevede sosyal medya araçlarıyla, aracılar, coğrafi sınırlar ya da büyük yatırımlar olmaksızın tüketicilerle iletişim kurmak ve hızlı bir biçimde geri bildirim almak mümkündür. Tüketiciler, sosyal medya ağlarında şirketler ya da ürünleriyle ilgili düşüncelerini sansürsüz bir ortamda hem diğer kullanıcılarla hem de şirketlerle paylaşabilmektedirler. Sosyal medya, tüketici gereksinimlerinin belirlenmesinde ve pazarın nabzının tutulmasında önemli yararlar sunmaktadır. İşletmeler, ürünlerini sosyal ağlarda aldıkları ilk geri bildirimlere göre yeniden şekillendirebilmekte ve bu sayede tüketici gereksinimlerini tam anlamiyla karşılayabilecek ürünlerin geliştirilmesi olanaklı hale gelmektedir. $\mathrm{Bu}$ durum, müşteri tatmininin önemli olduğu günümüz pazarlama anlayışlarında önemli bir kazanım olarak değerlendirilebilir.

Yeni ürün geliştirme, günümüzde firmaların büyüme stratejisi olmasından öte rekabet avantajı yaratması ve gelecekte de var olmaları açısından bir zorunluluktur. Pazara yeni ürün sunan bir firma rekabette avantaj sağlamaktadır. Ancak pazarda rekabet çok yüksek olduğundan bu yeni ürünün benzeri başka firmalar tarafindan bir süre sonra pazara sunulacak, dolayısıyla bu ürün artık firma için herhangi bir avantaj sağlamayacaktır. Teknolojik olarak gelişmiş olan ülkelerdeki yenilikler hızlı bir şekilde yayılmakta ve tüm tüketicilerin beklentilerini değiştirmektedir. Pazardaki yerlerini sürdürmek ve yoğun rekabete ayak uydurmak zorunda kalan firmalar tüm bu tüketici beklentilerini ancak yeni ürünler geliştirerek ve bu ürünleri marka haline dönüştürerek başarılı olabilirler. Yeni ürünlerin tüketici tarafından taşıdığ 1 riskleri azaltan en önemli faktörlerden biri de markadır. Yüksek marka değerine sahip firmalar, yeni ürünlerini pazara sunduklarında tüketiciler tarafindan önceki ürünleri ile aynı kalitede ve güvenilirlikte olduğu izlenimi ile karşılaşırlar.

Yeni ürünlerin uluslararası pazarlara sunumu, işletmelerin karşı karşıya kaldığı karmaşık kararlardan birisidir. Uluslararası pazarlardaki kültürel, sosyal, siyasal, inançsal farklılıklar bu karmaşıklığı artıran ve pazarlama uygulamalarının tüm yönlerine etki eden önemli faktörlerdir. Yeni ürünlerin kabul edilmelerine etki eden faktörleri anlamak, uluslararası pazarlama yöneticilerine, girecekleri pazarda yakalayacakları talep seviyesini tahmin etmelerini ve pazarın özelliklerine göre ürünleri üzerinde gerekli uyarlamaları yapmalarını sağlayacaktır.

İşletmelerin pazara sunacağı yeni ürünlerin tutunmasına ilişkin bazı öneriler şu şekilde siralanabilir:

- Her şeyden önce doğru ihtiyacın belirlenmesi ve ürünün müşteriye uygunluğu,

- Doğru maddi ve beşerî kaynakların kullanımı, 
- Doğru üretim süreci,

- Tüketici algısının doğru ölçülmesi ve doğru pazarlama kanalları yoluyla ürünün tüketicilere ulaştırılması,

- Tüketicilerin ürüne daha hızlı ulaşabilmeleri,

- E-ticaretin etkin şekilde yapılması,

- Yüksek teknolojiye dayalı üretim.

\section{Kaynaklar}

Aaker, David, (1996), Building Strong Brands, The Free Press, New York

Alkin, Erdoğan (1992), Gelir ve Büyüme Teorisi, Filiz Yayınları, İstanbul.

Alpugan, O. Demir M.H. Oktav, M. ve Üner, N. (1995), İsletme Ekonomisi ve Yönetimi, İstanbul: Beta Basım Yayım Dağıtım AS.

Altuğ, Nevin (2017), "İşletmelerde Yeni Ürün Geliştirme Çalışmaları ve Başarı Faktörleri”, Balkan ve Yakın Doğu Sosyal Bilimler Dergisi, 03 (02).

Aydemir, M. 1998. İşletmelerin Yasam Döngülerinin Uzatılmasına ilişsin Bir Çalışma, Yönetim ve Ekonomi-Celal Bayar Üniversitesi iktisadi ve idari Bilimler Fakültesi Dergisi, 4, 1-12.

Babacan, M. (2005), Reklamcılık: Temel Kavramlar, Ankara: Detay Yayınc1lık.

Bayraktar, Yüksel ve H. İbrahim Kaya (2016), "YENİ EKONOMİ VE DEĞİŞEN REKABET ANLAYIŞI: KARŞILAŞTIRMALI BİR ANALİZ", Bilgi Ekonomisi ve Yönetimi Dergisi / 2016 Cilt: XI Sayı: I.

Bayus, B.L. (1997), Speed to Market and New Product Performance Trade-offs,Journal of Product Innovation Management, 14, 486-499.

Cappo, J. (2004), Reklamcılı̆̆ın Geleceği. Çav. Fevzi YALIM, İstanbul: MediacatYayınları.

Churchill, A. Gilbert ve Peter, J. Paul. (1994), Marketing-Creating Value for Customers. Austen Press. USA:

Czinkota, M.R. Masaaki K. ve Mercer D. (1997), Marketing Management, Blackwell Publishers İnç, USA.

Cooper, G.R. ve Kleinschmidt, E.J. (1994), Determinants and Timeliness in Product Development, Journal of Product Innovation Management, 11, 381402.

Crawford, M. ve A. Di Benedetto (2008), New Products Management, Ninth Edition, McGrawHill International Edition.

Dolanbay, C. (2000), E-ticaret Strateji ve Yöntemler.

Elitok, Bülent (2003), Hadi Markalaşalım, Sistem Yayıncılık, İstanbul

Enes, S. (2002), Elektronik Ticarette Tüketicinin Korunması ve Bir Uygulama.

Erdil, Erkan, M. Teoman Pamukçu, İ. Semih Akçomak ve Murad Tiryakioğlu (2016), "Bilgi, Bilim, Teknoloji ve Yenilik: Kavramsal Tartışma", ODTÜ TEKPOL Bilim ve Teknoloji Politikaları Araştırma Merkezi, TEKPOL Working Paper Series STPS-WP-16/01, Ankara (http://stps.metu.edu.tr/sites/stps.metu.edu.tr/files/WP\%2016\%3A01_1.pdf, 30.08.2017; Bu metin Erkan Erdil, M. Teoman Pamukçu, İ. Semih Akçomak ve Murad 
Tiryakioğlu editörlüğünde Bilgi Üniversitesi Yayınları tarafından 2016 yılı içinde basılacak Bilim, Teknoloji ve Yenilik: Kavramlar, Kuramlar ve Politika isimli kitapta yayınlanacaktır.)

Eugene S. ve Dwyer F.R. 2000. An Examination of Organizational FactorsInfluencing New Product Success in Internal and Alliance-BasedProcesses, Journal of Marketing, 64, 3144.

Evans, R.J. ve Berman B. (1992), Marketing, MacMillan Publishing Company. 5.Edition, USA.

Feşel, N. Nilgün (2014), "Yeni Ürün Geliştirme”, ODTÜ Endüstri Müh. Böl. Doktora Sonrası Araştırma Prog., Kalkınmada Anahtar Verimlilik Dergisi, Sayı: 30 (https://anahtar.sanayi. gov.tr/tr/news/-urun-yonetimi-3-yeni-urun-gelistirme/1856, 20. 06.2017).

Gobeli, D.H. ve Brown, D. (1987), Analyzing Product Innovations, ResearchManagement, 30, 25-26.

Gürsel, Z. H. (1979), Firma Açısından Yeni Ürünlerin Planlanması ve Değerlendirilmesi, Ankara Üniversitesi, Ankara.

Haines, S. (2009), The Product Manager's Desk Reference, McGraw-Hill.

Hatipoğlu, Zeyyat, (1993), Temel Pazarlama, Beta Yayıncılık, İstanbul

Hofstede Geert (1983), “The Cultural Relativity Of Organizational Practices And Theories", Journal Of International Business Studies, V:14 I:2.

http://stratejinibelirle.blogspot.com.tr/2012/05/rekabetin-5-onemli-unsuru.html, 18.09.2017.

http://tdk.gov.tr/index.php?option=com_bts\&arama=kelime\&guid=TDK.GTS.59a71de0be56f 9.02939672, 30.08.2017; BSTS / İktisat Terimleri Sözlügü 2004; BSTS / Toplumbilim Terimleri 1975.

http://www.rgsyazilim.com/e-ticaretin-tarihcesi/, 20,06.2017.

https://www.slideshare.net/webrazzi/trkiye-eticaret-raporu-2017-turkish-ecommerce-report, 17.09.2017.

Kavadias, S. ve R.O. Chao (2008), Resource Allocation and New Product Development Portfolio Management, Appear in: Loch, C.H., and Kavadias S. (eds.), Handbook of New Product Development Research, Oxford: Elsevier/Butterworth.

Keller, Kevin Lâine, (2001), Building Customer-Based Brand Equity, MarketingManagement s. 14.

Kelz K.L. (1998), Strategic Brand Management: Building, Measuring andManaging Brand Equity, Prentice Hall, USA.

Kotler, Philip, (2000), Marketing Management, The Millennium Edition, Prentice-Hall International Editions, New Jersey

Kotler, P. (1998), Marketing Management-Analysis, Implementation, Planning andControl, Prentice Hall, 9. Edition, USA.

Knapp, Duane, (2000), Marka Akli, MediaCat Kitapları, İstanbul

Kulwant, Power, Unny, S.M. ve Riedel, J. (1994), Time to Market, IntegratedManufacturing Systems, 5, 12-26. 
Lury, G. (1998), Brandwatching, Blackhall Publising, Dublin.

Malpezzi, Stephen (2002), "Urban Regulation, The "New Economy" and Housing Prices", Housing Policy Debate, Volume 13, Issue 2, p: 323-349.

McCarthy, E.Jerome \& Perrault William D. (1990), Basic Marketing, USA.

Mucuk, İsmet, (2000), Pazarlama İlkeleri, Türkmen Kitapevi, İstanbul.

Nakata, Cherly ve SIVAKUMAR, K. (2001), "Instituting The Marketing Concept In a Multinational Setting: The Role of National Culture", Academy of Marketing Science, Vol:29, Iss:3.

Nilson, T.H. (1998), Competitive Branding, Wile, Chickers

Oğuztürk, B. Sami (2003), "Yenilik Kavramı ve Teorik Temelleri”, Süleyman Demirel Üniversitesi İİBF Dergisi, Cilt: 8, Say1: 2.

Perreault, W. D., Cannon J. P. ve McCarthy, E. J. (2013), Pazarlamanın Temelleri, Nobel Yayınları, McGraw-Hill\&Irwin.

Porter, Michael, (2003), Rekabet Stratejisi, Sistem Yayıncılık, İstanbul.

Powers, L. Thomas, (1991), Modern Business Marketing, West Publising Company, Birmingham.

Ring, Jim (1996), Reklam Dünyasının Içyüzü: Başarılı Sonuçlar Almak Için Reklam Ajanşınızı Nasıl Yönetmelisiniz, AD Yayıncılık.

Ringman, T. (1996), Windows of Opportunity: Timing and Entry Strategies, International Management and Data Systems, 96, 26-31.

Sezgin, Aslı G. Şat (2013), Dünyada ve Türkiye'de E-Ticaret Sektörü, Türkiye İş Bankası İktisadi Araştırmalar Bölümü.

Shaw, G. Brown, R. ve Bromiley, P. (1998), Strategic Stories: How 3M is RewritingBusiness Planning, Harward Business Review, 76, 41-51.

Solomon, M.R. ve Stuart E.W. (2002), Marketing, Real Choices, 6th.ed., Prentice Hall, New Jersey.

Süzen, Cömert (2001), Kültürel Çevrenin Uluslararası İşletmeler Acısından Önemi, Türkiye Kültürel Yapısı ve Uluslararası İşletmeler Üzerindeki Etkileri, İstanbul, Marmara Üniversitesi Yüksek Lisans Tezi.

Terpstra, V. ve Sarathy, R. (1994), International Marketing, Sixth Edition, TheDryden Press, London.

Turgay, T. (1994), Yeni Ürün Düşüncesi ve Firmalar Açısından Etkinliği, Eskişehir Anadolu Üniversitesi iktisadi ve idari Bilimler Fakültesi Dergisi, 1-2,66-69.

Türkmen, İ. (1996), Reklam Yönetimi, Ankara: Milli Prodüktivite Merkezi Yayınları, No:583.

Walley, K. (1998), Competition: What does it really mean? The TQM Magazine, 10, 186-189.

Wilmshurtst, John, (1988), The Fundamentals and Practice of Marketing,Heinemann Professional Publising Ltd, Oxford

Winer R. (2000), Marketing Management. Prentice Hall, International Ltd., New Jersey. 


\section{EXTENDED SUMMARY}

\section{The Factors Affecting Promotion of New Products Put in Market by the Companies}

The necessities arising from the existence of mankind have been tried to be met with various products and services. Products and services have diversified and renewed from the past in the direction of technological developments. While providing businesses with products and services tailored to their needs, new products and services produced with technological opportunities from the other side have made people's lives easier. The production process has also changed in the direction of these developments. Especially the Industrial Revolution, this change is one of the most important historical turning points. Innovation, which started with the mechanization of production by the Industrial Revolution, continues to gain momentum with rapid developments in information-communication technologies. This process has facilitated the production, use and storage of information, and in a sense the businesses have equalled the competitive advantages. However, enterprises have a competitive advantage in designing and marketing new products by accurately identifying consumer demands.

In a world where the globalization process continues unabated, one of the important factors affecting the ability of businesses to withstand national and international competition is the ability to hold new products offered for sale in the market. The fact that products meet the needs certainly affects consumers' purchasing preferences, but these products can become more competitive in design, quality and price using new technologies.

Developing new products and presenting bazaar is a difficult, costly and dangerous business, but a necessity for companies. Another reason for developing new products is to increase profitability. The concept of the new product has come to terms with concepts such as original product, improved product, modified product. There must be a product idea before the new product development process begins. The process of uncovering new ideas should be implemented carefully and systematically. Only a few of the new product ideas can reach the stage of product development as a result of all the analyses and procedures. Therefore, new product development is a process that requires high cost as well as effective market research and intensive marketing activities.

This study on the affixation of new products presented on the market is based on the analysis and synthesis of the information obtained especially by literature review.

Some suggestions for holding new products that businesses can offer are as follows:

- first of all, determining the right need and the suitability of the product to the customer,

- the use of direct material and human resources,

- direct production process,

accurate measurement of consumer perception and delivery of products to consumers through the right marketing channels,

- that consumers can get to the product faster,

-effectively making e-commerce,

- high technology based production. 